\title{
Survey on the chemical composition of several tropical wood species
}

Jean GÉRARD ${ }^{1,2}$

Sébastien PARAdIS ${ }^{1,2}$

Bernard THIBAUT $^{3}$

${ }^{1}$ CIRAD

UPR BioWooEB

34398 Montpellier

France

\section{${ }^{2}$ BioWooEB}

Univ Montpellier, CIRAD

Montpellier

France

\section{${ }^{3}$ LMGC}

Univ Montpellier

CNRS

Montpellier

France

\section{Auteur correspondant /} Corresponding author:

Bernard Thibaut -

bernard.thibaut@umontpellier.fr

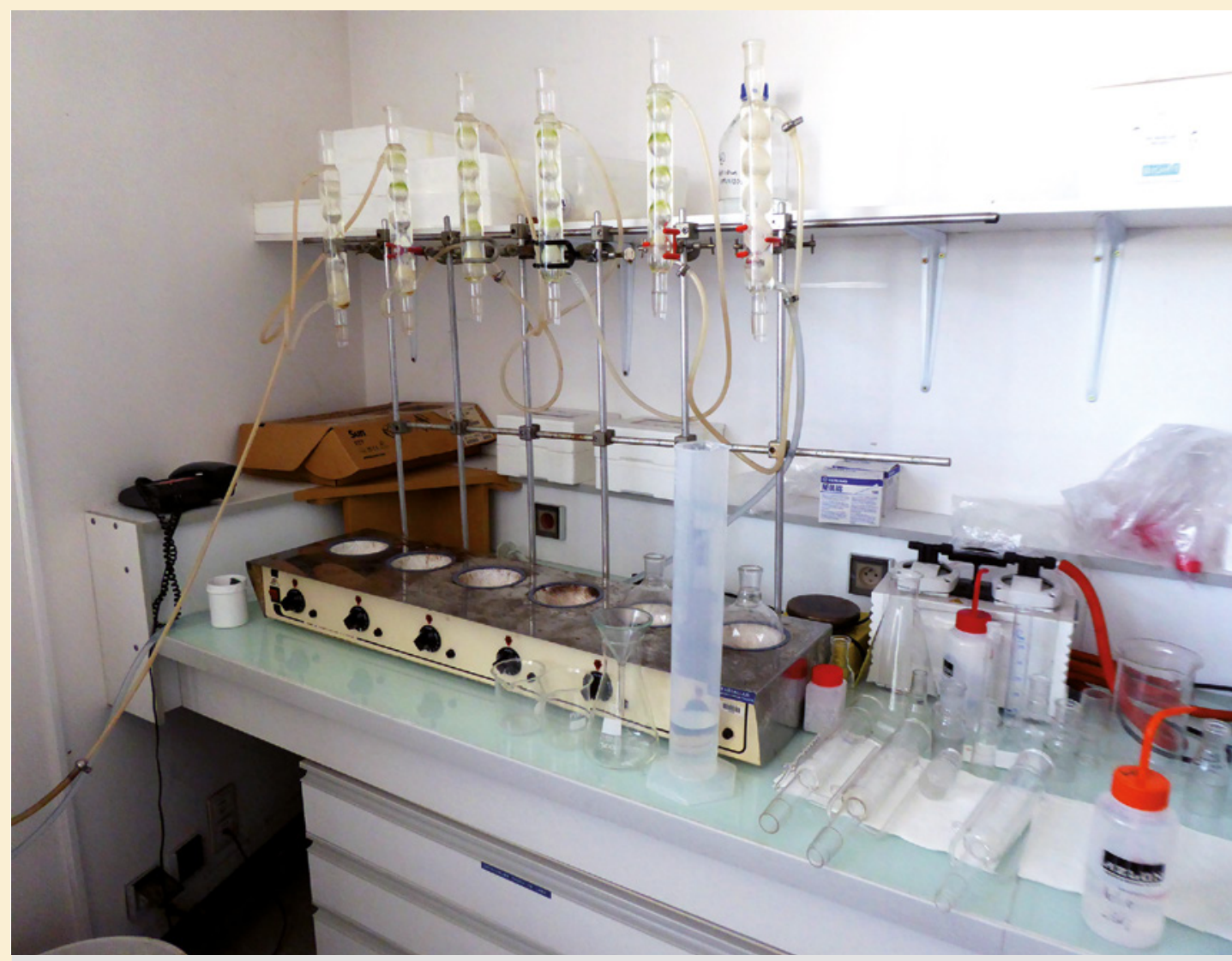

Photo 1.

Extraction ramp (Chemistry Laboratory of the BioWooEB Unit - CIRAD).

Photo J. Gérard.

Doi : 10.19182/bft2019.342. a31809 - Droit d'auteur @ 2019, Bois et Forêts des Tropiques @ Cirad - Date de soumission : 30 novembre 2018 ; date d'acceptation : 11 juin 2019 ; date de publication : 30 octobre 2019.



Licence Creative Commons :

Attribution - Pas de Modification 4.0 International.

Attribution-NoDerivatives 4.0 International (CC BY-ND 4.0)
Citer l'article / To cite the article

Gérard J., Paradis S., Thibaut B., 2019. Survey on the chemical composition of several tropical wood species. Bois et Forêts des Tropiques, 342: 79-91. Doi : https://doi.org/10.19182/bft2019.342.a31809 


\section{RÉSUMÉ}

\section{Suivi de la composition chimique de plusieurs espèces de bois tropicaux}

La variabilité de la composition chimique de 614 espèces est décrite dans une base de données contenant des mesures de polymères du bois (cellulose, lignine et pentosane), ainsi que de l'ensemble des composants externes (extraits éthanolbenzéne ou à l'eau chaude et cendres, en particulier la teneur en silice). Ces mesures ont été effectuées entre 1945 et 1990 selon le même protocole standard. Au total, 1194 arbres appartenant à 614 espèces, 358 genres et 89 familles ont été mesurés. La variabilité entre les espèces (quantifiée par le coefficient de variation) était plutôt élevée pour la densité (27\%), beaucoup plus faible pour la lignine et la cellulose (14\% et $10 \%)$ et beaucoup plus élevée pour les extractibles éthanol/benzène, les extractibles à l'eau chaude et les cendres ( $81 \%, 60 \%$ et $76 \%$ ). En considérant des arbres avec au moins cinq spécimens différents et des espèces avec au moins 10 arbres différents, il a été possible d'étudier la variabilité intra-arbre et intraespèce. De grandes différences ont été constatées entre les arbres d'une espèce donnée pour les composants externes, et plus d'un arbre devrait être nécessaire par espèce. Pour la densité, la lignine, le pentosane et la cellulose, la distribution des valeurs était presque symétrique, avec des valeurs moyennes de $720 \mathrm{~kg} / \mathrm{m}^{3}$ pour la densité, 29,1\% pour la lignine, $15,8 \%$ pour le pentosane et $42,4 \%$ pour la cellulose. La teneur en lignine variait nettement d'une espèce à l'autre. Pour les composants externes, la distribution était très dissymétrique, avec une minorité de bois riches en ce composant constituant la queue de valeurs élevées. Une valeur élevée pour tout composant externe, même dans un seul arbre, est suffisante pour classer l'espèce à l'égard de ce composant. Les bois siliceux identifiés par les cristaux de silice en anatomie ont une teneur très élevée en silice et seules ces espèces méritent une étude sur la silice.

Mots-clés : composants du bois, cellulose, lignine, pentosane, éthanolbenzène, eau, cendres, silice, chimie du bois, espèces tropicales, base de données.

\section{ABSTRACT}

\section{Survey on the chemical composition of several tropical wood species}

Variability in the chemical composition of 614 species is described in a database containing measurements of wood polymers (cellulose, lignin and pentosan), as well as overall extraneous components (ethanol-benzene, or hot water extracts and ash, with a focus on silica content). These measurements were taken between 1945 and 1990 using the same standard protocol. In all, 1,194 trees belonging to 614 species, 358 genera and 89 families were measured. At species level, variability (quantified by the coefficient of variation) was rather high for density (27\%), much lower for lignin and cellulose (14\% and $10 \%)$ and much higher for ethanol/benzene extractives, hot water extractives and ash content (81\%, 60\% and $76 \%$ ). Considering trees with at least five different specimens, and species with at least 10 different trees, it was possible to investigate within-tree and withinspecies variability. Large differences were found between trees of a given species for extraneous components, and more than one tree should be needed per species. For density, lignin, pentosan and cellulose, the distribution of values was nearly symmetrical, with mean values of $720 \mathrm{~kg} / \mathrm{m}^{3}$ for density, $29.1 \%$ for lignin, $15.8 \%$ for pentosan, and $42.4 \%$ for cellulose. There were clear differences between species for lignin content. For extraneous components, the distribution was very dissymmetrical, with a minority of woods rich in this component composing the high value tail. A high value for any extraneous component, even in only one tree, is sufficient to classify the species in respect of that component. Siliceous woods identified by silica bodies in anatomy have a very high silica content and only those species deserve a silica study.

Keywords: wood components, cellulose, lignin, pentosan, ethanol-benzene, water, ash, silica, wood chemistry, tropical species, database.

\section{RESUMEN}

\section{Estudio de la composición química de varias especies de maderas tropicales}

La variabilidad de la composición química de 614 especies se describe en una base de datos que contiene las medidas de polímeros de madera (celulosa, lignina y pentosano), así como del conjunto de los componentes externos (etanol-benceno, o extractos de agua caliente y cenizas, especialmente el contenido de sílice). Estas medidas se efectuaron entre 1945 y 1990 según el mismo protocolo estándar. En total, se midieron 1194 árboles pertenecientes a 614 especies, 358 géneros y 89 familias. En cuanto a las especies, la variabilidad (cuantificada por el coeficiente de variación) era más bien elevada para la densidad (27\%), mucho más débil para la lignina y la celulosa (14\% y $10 \%)$ y mucho más elevada para los componentes extraíbles etanol/benceno, los componentes extraíbles con agua caliente y las cenizas ( $81 \%, 60 \%$ y $76 \%$ ). Considerando los árboles con al menos cinco muestras diferentes y especies con al menos 10 árboles diferentes, fue posible estudiar la variabilidad intraárboles e intraespecies. Se constataron grandes diferencias entre los árboles de una determinada especie para los componentes externos, y debería ser necesario más de un árbol por especie. Para la densidad, la lignina, el pentosano y la celulosa, la distribución de los valores es casi simétrica, con valores medios de $720 \mathrm{~kg} / \mathrm{m}^{3}$ para la densidad, $29,1 \%$ para la lignina, $15,8 \%$ para el pentosano y $42,4 \%$ para la celulosa. El contenido en lignina varía claramente de una especie a otra. Para los componentes externos, la distribución es muy disimétrica, con una minoría de maderas ricas en este componente, que constituye un larga cola de gran valor. Un valor elevado para cualquier componente externo, incluso en un solo árbol, es suficiente para clasificar la especie en función de este componente. Las maderas silícicas identificadas por los cuerpos de sílice en anatomía tienen un contenido muy elevado de sílice y solo estas especies merecen un estudio sobre la sílice.

Palabras clave: componentes de la madera, celulosa, lignina, pentosano, etanol-benceno, agua, cenizas, sílice, química de la madera, especies tropicales, base de datos. 


\section{Introduction}

The use of wood for pulp and paper making was the result of German inventions in the second part of the $19^{\text {th }}$ century, and the wood-based pulp industry grew quickly at the beginning of the $20^{\text {th }}$ century (Ek et al., 2009). The Technical Association of the Pulp and Paper Industry (TAPPI ${ }^{1}$ ) was founded in 1915 and there was demand for more knowledge about wood chemistry. The Chemistry of Wood (Hawley and Wise, 1926) was the first reference book on the subject, with a large discussion about methods for analysing carbohydrate (cellulose, hemicelluloses, pectin), lignin, extractives and ash. Methods were discussed at TAPPI meetings, leading to official standards for extractives in 1933 (T 204), ash in 1934 (T 211), pentosan in 1948 (T 223) and lignin in 1954 (T 222).

In France, there was a request in the 1940 s to carry out a feasibility analysis for pulp and paper making using forest resources from tropical countries in the French colonies and overseas departments (Le Cacheux, 1949). The very wide diversity of species in each forest plot was a challenge. From the outset, two alternatives were examined: single-species plantations, or mixing a rather large number of dominant species (fewer than 20) from a large natural forest zone (Quint, 1951). Pulp and paper tests were performed at laboratory and industrial levels in the two cases (Pétroff, 1965, 1976). Although pulp can be obtained using a large diversity of species, technical problems were substantial and the economic outcome was doubtful (Pétroff, 1960, 1976; Tissot, 1989).

Knowledge of the chemical composition of the selected species was needed and that objective was launched by a State PhD thesis (Morize, 1953) dedicated to setting up, within the CTFT (French Technical Centre for Tropical Forests) cellulose division, the best protocols for tropical woods using the state of the art discussed at TAPPI meetings. Methods were precisely described in the thesis, which was reproduced in its entirety in a reference book (Savard et al., 1954) and further discussed in a second book (Savard et al., 1959). They were very similar to those from the US Forest products laboratory (Pettersen, 1984) and were constantly used in the laboratory up to 1990.

We believe that there was no variation within the standard protocol for the following reasons: all the measurements were performed in the same laboratory, with the same equipment, by technicians well trained for "quality work" although it was not yet an ISO standard (two of the authors were colleagues of these persons from 1973 to 1994). Two thirds of the measurements

${ }^{1}$ http://www.tappi.org/ were carried out between 1946 and 1961 (figure 1). Between 1964 and 1990, the effort was much more limited, mainly linked to the use of tropical wood for energy purposes (Doat, 1977; Pétroff and Doat, 1978) and to new interest in the pulp and paper industry in French Guiana (Tissot, 1989).

In order to check possible changes we look at variations of results during succeeding years. There are no significant differences between periods except for the species sampling, much larger in the first period. We have decided to open these data files to the scientific community because we trust in its quality, in terms of continuity.

Mostly hardwood species (599) were measured, including a very small number of temperate hardwood species (5), with only 15 gymnosperm species being included. Seven basic parameters are discussed: hot water extracts, ethanol-benzene extracts, ashes, silica content within ashes, Klason lignin, pentosan, Kürschner cellulose.

\section{Methods}

The analytical methods were largely described and discussed in the two reference books (Savard et al., 1954, 1959), and they were very similar to those described in Pettersen (1984). We will just give a summary of the methods used to measure the presented parameters.

\section{Sample production}

All specimens came from trees with a reference in the CIRAD collection (Langbour et al., 2019). The basic specimen was a clear-wood rod measuring $34 \mathrm{~cm}$ (L direction) $\times 2 \mathrm{~cm}$ (R direction) $\times 2 \mathrm{~cm}$ (T direction) delivered by the carpenter's workshop (same specimen as for flexure testing).

Each rod was chipped using a standardized procedure. The chips (50 g of air-dried wood) were milled into wood powder by centrifugal separation $(12,000 \mathrm{rpm})$ with breaks every 30 minutes in order to avoid excessive heating.

. 
A 40-mesh (40 square apertures per inch, or $6.4 \mathrm{~mm}$ side length) followed by a second 80 -mesh (80 square apertures per inch or $3.2 \mathrm{~mm}$ side length) was used to obtain a calibrated 40/80 powder for chemical analysis.

\section{First step, ethanol/benzene extract (AB ext)}

$A B$ is the acronym for a $1 / 1$ volume-based ethanol $\left(95^{\circ}\right) /$ benzene (pure) mixture used to extract most organic materials that are insoluble in water. Twenty to $25 \mathrm{~g}$ of $40 / 80$ powder was placed in a Soxhlet extraction apparatus with the mixture for a total of 8 hours' extraction, before passing through ether solvent for 6 hours (10' each time). Relative mass loss (as compared to anhydrous wood gross weight) after total drying $\left(105^{\circ} \mathrm{C}\right)$ was used for the $A B$ extract value.

$A B$ extraction was always carried out before all the other analyses, except for silica content.

\section{Water extract (W ext)}

Hot water (at boiling temperature) can extract mineral salts, tannins, starch, gums and some sugars. The protocol was: $1.5 \mathrm{~g}$ of powder (after $A B$ extraction) in $100 \mathrm{~mL}$ of hot water for 8 hours. Relative mass loss (as compared to anhydrous wood gross weight before $A B$ extraction) after total drying $\left(105^{\circ} \mathrm{C}\right)$ was used for the water extract value.

\section{Ash content (Ash)}

Total ash content was obtained after incineration in an electric oven at $425 \pm 10^{\circ} \mathrm{C}$, using $1.5 \mathrm{~g}$ of powder up to constant mass in the oven.

\section{Silica content (Sil)}

Silica often only amounts to a few percent of ash content, which in turn accounts for less than $1 \%$ of dry wood mass. In order to use $1 \mathrm{~g}$ of ash, it takes a rather large amount of initial wood mass. Small wood sticks (larger than a big match) were calcined at $425^{\circ} \mathrm{C}$ to obtain at least $1 \mathrm{~g}$ of ash for silica analysis. Its purity was confirmed by hydrofluoric acid action (Besson, 1946).

\section{Lignin (Lig)}

Lignin content was measured using the Klason method (Pettersen, 1984). Sulphuric acid at a concentration of $67 \%$ was used in a ratio of $30 \mathrm{~mL}$ of acid for $1.5 \mathrm{~g}$ of powder after $A B$ extraction. The value reported in the table of results is the mass ratio of dried lignin to wood gross dry weight.

\section{Pentosans (Pent)}

For hardwoods, five carbon sugars (pentosans) are the major hemicelluloses (often above $80 \%$ ), and they were measured using furfural analysis. A $100 \mathrm{~mL}$ volume of hydrochloric acid at $13.2 \%$ was used for 0.5 to $0.7 \mathrm{~g}$ of $A B$ extracted powder.

\section{Cellulose (Cell)}

The Kürschner and Hoffer method was used. A water bath regulated at water boiling temperature was used with a $50 \mathrm{ml}$ solution of 1 volume of nitric acid at $48^{\circ}$ Baumé +4 volumes of $95^{\circ}$ alcohol for $1.5 \mathrm{~g}$ of $A B$ extracted powder, for 1 hour. After washing with alcohol and filtration, the extraction process was repeated three more times (total of four extraction processes), after which the extract was dried at $105^{\circ} \mathrm{C}$ after washing and rinsing in alcohol and ether.

\section{Balance (Total)}

Summation of the $A B$ extract + Water extract + Ash + Lignin + Pentosan + Cellulose parameters should be near the $100 \%$ value (a total above $100 \%$ can be due to a small difference resulting from uncertainties throughout the processes). The main reason for rather large differences was the lack of six carbon sugar hemicelluloses constituents, mainly for gymnosperms, where they generally account for around half the hemicelluloses content. However, some analyses of mannan and galactan for tropical hardwoods (Savard et al., 1954, 1959; Pettersen, 1984) have proved that these six carbon sugar contents in hemicelluloses can be over $5 \%$ of hardwood gross dry mass. This means that the tables do not give a value for the total hemicelluloses content, but the difference between the balance and 100 is mostly representative of the share of hemicelluloses that are not taken into account in pentosan.

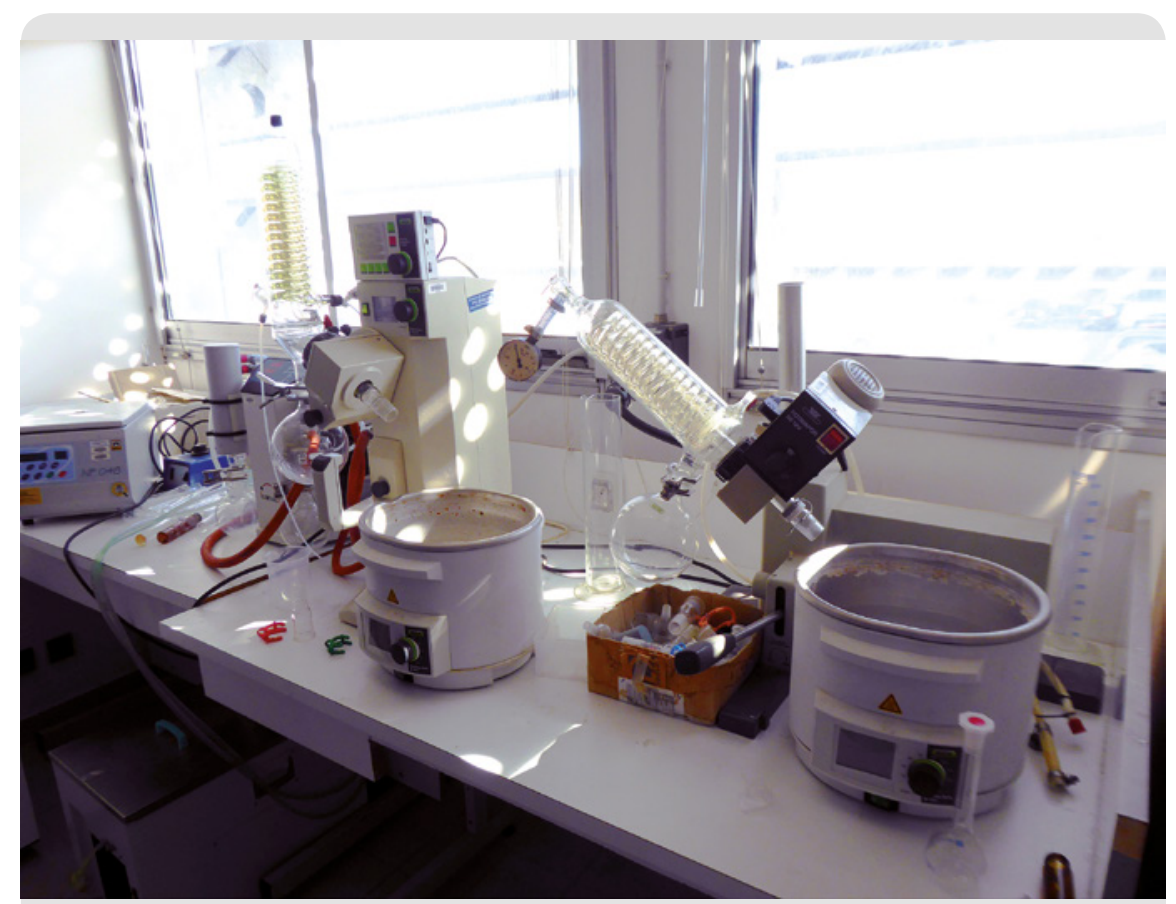

Photo 2.

Rotary evaporators (Chemistry Laboratory of the BioWooEB Unit - CIRAD). Photo J. Gérard. 


\section{Database and statistical methods}

All the informative data and metadata on the collection have been recorded in digital files since 1980 (Gérard and Narboni, 1996). In the data file associated with this paper, the botanical names have been updated and mean density values have been added at species level (unless there was a density value associated with the CTFT id in the wood collection).

Basic statistical analyses were performed using XLSTAT software. The data description table includes the number of present and missing data, minimum, maximum, $1^{\text {st }}$ quartile, median, $3^{\text {rd }}$ quartile and mean (with its standard deviation) values for each parameter, as well as the coefficient of variation (CV), skew (Pearson) and kurtosis (Pearson) of the distribution. A box plot is also given for each parameter. The box plot figures the quartiles (the band inside the box is the median). Whiskers plot the lowest data item still within the 1.5 IQR (inter quartile range) of the lower quartile, and the highest data item still within the 1.5 IQR of the upper quartile.

For the histogram presentation, the amplitude was chosen for each parameter, in order to have a clear description of the data. Normality of distribution was verified by four tests: Shapiro-Wilk, Anderson-Darling, Lilliefors and Jarque-Bera. In the case of normal distribution, a Pearson type correlation analysis was used, and a Spearman type for non-normal distribution.

\section{Description of the database}

There are five data sheets and one comment sheet.

\section{Test sheet}

This gathers the results for 1,287 complete tests (all parameters present, except for some missing silica contents), in CTFT reference numerical order with 15 columns: Test (range of the set of measurements), Year, Tree, Origin, Family, Species, Density (density values available in the wood collection), AB ext, W ext, Ash, Silica, Lignin, Cellulose, Pentosan, Balance. There are 32 trees with more than one set of measurements (from 2 to 17).

\section{Tree sheet}

This gathers the results for 1,194 trees. It was built from the Test sheet, by calculating the mean parameter values for each tree.

\section{Species sheet}

This gathers the results for 614 species. It was built from the Tree sheet, by cal- culating mean parameter values for each species. Missing density values (not measured in the wood collection) for the species were collected from existing Internet literature (some values are still missing).

\section{Genus sheet}

This gathers the results for 358 genera. It was built from the Species sheet, by calculating mean parameter values for each genus.

\section{Family sheet}

this gathers the results for 89 families. It was built from the Genus sheet, by calculating mean parameter values for each family. An additional line gives the mean value for gymnosperms represented by only 4 families ( 8 genera and 15 species).

\section{Global distribution of values}

The distribution of values for all measurements $(1,287)$ in the test sheet is presented in figure 1 and figure 2 . For all extraneous components (figure 2), the distribution was highly dissymmetrical, with a rather small number of values much higher than the great majority. Total values for these extraneous components were often above 15\% (sometimes above $25 \%$ ). This could introduce bias in the composition of the main cell wall components.

For density, balance, cellulose, lignin and pentosan content (figure 3), the distribution was nearly symmetrical, with a very wide range in density, representative of tropical species in the collection.

\section{Within-tree level}

There were very few cases of measurements on different specimens within the tree (always in heartwood). Using those with at least five specimens in one tree (10 trees belonging to 8 species), it was possible to take a look at the within-tree variability of chemistry (figure 1 , table I).

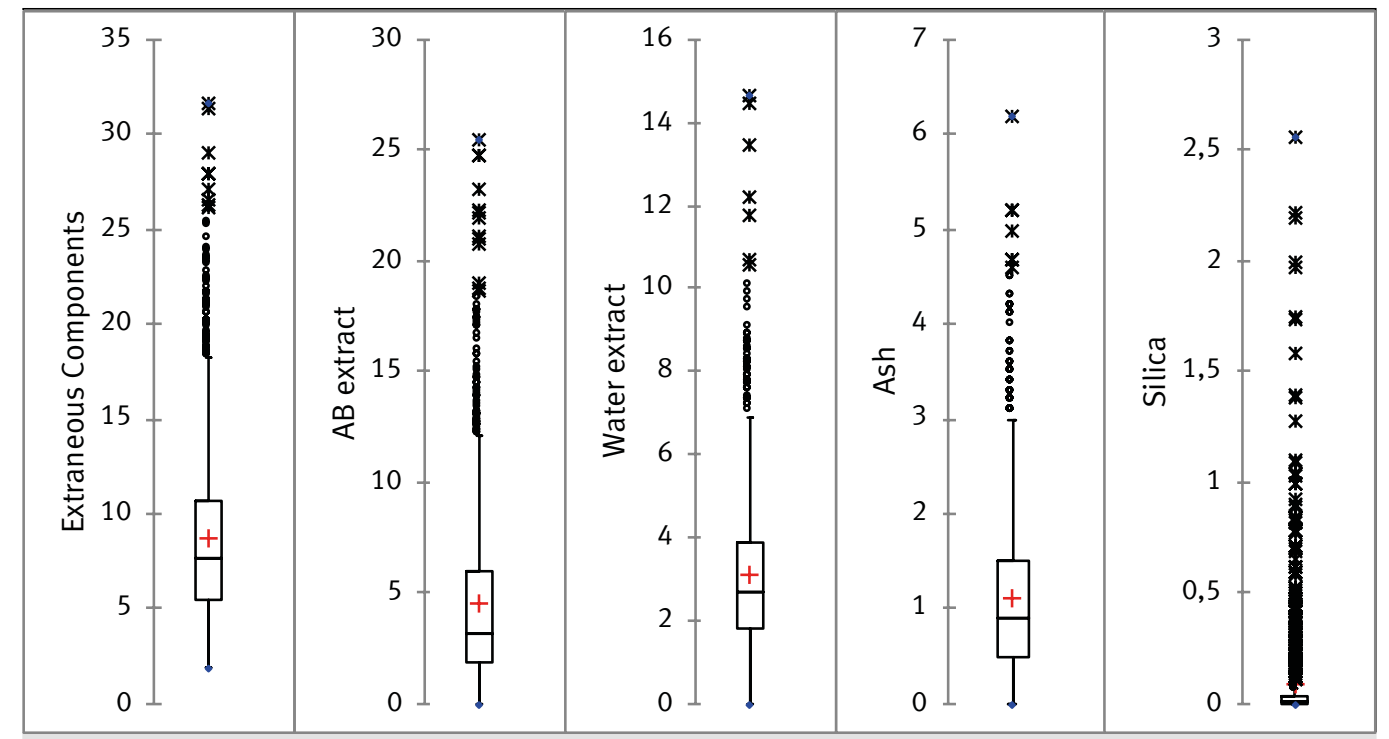

Figure 2.

Distribution of extraneous components for all tests $(1,287)$. Values as a \% related to anhydrous wood mass. Extraneous components: AB extract + Water extract + Ash. 
Table I.

Variability within trees represented by at least five tests. Top: mean values; bottom: coefficient of variation; Id: CTFT identifier; Nb: number of tests for the tree; CV: coefficient of variation of mean values per species; D: density of the reference specimen for the tree in the wood collection; $A B$ ext: ethanol/benzene extract; W ext: water extract; Ash: ash content; Sil: silica content; Lig: lignin content; Pent: pentosan content; Cell: cellulose content.

\begin{tabular}{|c|c|c|c|c|c|c|c|c|c|c|}
\hline Tree & Id & $\mathrm{Nb}$ & D & $A B$ ext & W ext & Ash & Sil & Lig & Pent & Cell \\
\hline Dacryodes edulis & 17722 & 5 & 0.59 & 1.90 & 2.68 & 1.54 & 0.4000 & 30.3 & 15.1 & 44.8 \\
\hline Dacryodes sp. & 17878 & 5 & 0.47 & 2.54 & 4.42 & 1.30 & 0.1625 & 31.3 & 17.1 & 39.6 \\
\hline Octoknema sp. & 17857 & 6 & 0.61 & 2.63 & 2.97 & 1.95 & 0.0070 & 32.0 & 12.3 & 44.7 \\
\hline Casearia sp. & 17893 & 5 & 0.69 & 1.02 & 3.44 & 3.68 & 0.0033 & 31.6 & 14.0 & 43.7 \\
\hline Strombosia grandifolia & 17930 & 5 & 0.81 & 2.10 & 2.48 & 1.32 & 0.0033 & 33.7 & 12.8 & 44.5 \\
\hline Hibiscus tiliaceus & 18110 & 7 & 0.34 & 5.44 & 2.87 & 1.81 & & 29.5 & 14.2 & 44.8 \\
\hline Terminalia superba & 18421 & 17 & 0.46 & 3.14 & 4.37 & 3.44 & 0.0074 & 31.0 & 12.3 & 44.2 \\
\hline Terminalia superba & 18728 & 8 & 0.52 & 2.85 & 5.18 & 1.80 & 0.0030 & 29.1 & 16.0 & 42.2 \\
\hline Terminalia superba & 19041 & 8 & 0.4 & 1.83 & 3.75 & 2.30 & 0.0054 & 30.8 & 12.9 & 47.2 \\
\hline Terminalia superba & 19042 & 8 & 0.55 & 1.83 & 4.06 & 2.28 & 0.0041 & 30.1 & 13.8 & 44.6 \\
\hline Mean & & & 0.54 & 2.53 & 3.62 & 2.14 & 0.0662 & 30.9 & 14.0 & 44.0 \\
\hline Tree & Id & $\mathrm{Nb}$ & D & CV AB ext & CV W ext & CV Ash & CV Sil & CV Lig & CV Pent & CV Cell \\
\hline Dacryodes edulis & 17722 & 5 & 0.59 & $28 \%$ & $19 \%$ & $25 \%$ & $16 \%$ & $3.8 \%$ & $6.4 \%$ & $4.6 \%$ \\
\hline Dacryodes sp. & 17878 & 5 & 0.47 & $23 \%$ & $12 \%$ & $20 \%$ & $12 \%$ & $2.9 \%$ & $1.2 \%$ & $4.8 \%$ \\
\hline Octoknema sp. & 17857 & 6 & 0.61 & $23 \%$ & $25 \%$ & $9 \%$ & $103 \%$ & $6.5 \%$ & $4.0 \%$ & $3.8 \%$ \\
\hline Casearia sp. & 17893 & 5 & 0.69 & $24 \%$ & $19 \%$ & $4 \%$ & $141 \%$ & $4.4 \%$ & $5.5 \%$ & $4.4 \%$ \\
\hline Strombosia grandifolia & 17930 & 5 & 0.81 & $29 \%$ & $62 \%$ & $10 \%$ & $46 \%$ & $5.5 \%$ & $5.6 \%$ & $6.9 \%$ \\
\hline Hibiscus tiliaceus & 18110 & 7 & 0.34 & $39 \%$ & $29 \%$ & $10 \%$ & & $4.3 \%$ & $5.9 \%$ & $2.8 \%$ \\
\hline Terminalia superba & 17828 & 5 & 0.35 & $21 \%$ & $25 \%$ & $16 \%$ & $56 \%$ & $7.2 \%$ & $6.0 \%$ & $3.0 \%$ \\
\hline Terminalia superba & 18421 & 17 & 0.46 & $28 \%$ & $39 \%$ & $22 \%$ & $82 \%$ & $2.7 \%$ & $3.9 \%$ & $8.8 \%$ \\
\hline Terminalia superba & 18728 & 8 & 0.52 & $6 \%$ & $4 \%$ & $22 \%$ & $80 \%$ & $4.2 \%$ & $5.0 \%$ & $3.3 \%$ \\
\hline Terminalia superba & 19041 & 8 & 0.40 & $18 \%$ & $30 \%$ & $23 \%$ & $76 \%$ & $2.7 \%$ & $5.6 \%$ & $3.4 \%$ \\
\hline Terminalia superba & 19042 & 8 & 0.55 & $36 \%$ & $10 \%$ & $20 \%$ & $156 \%$ & $2.9 \%$ & $5.7 \%$ & $3.8 \%$ \\
\hline Mean & & & 0.53 & $25 \%$ & $25 \%$ & $16 \%$ & $77 \%$ & $4.3 \%$ & $5.0 \%$ & $4.5 \%$ \\
\hline
\end{tabular}

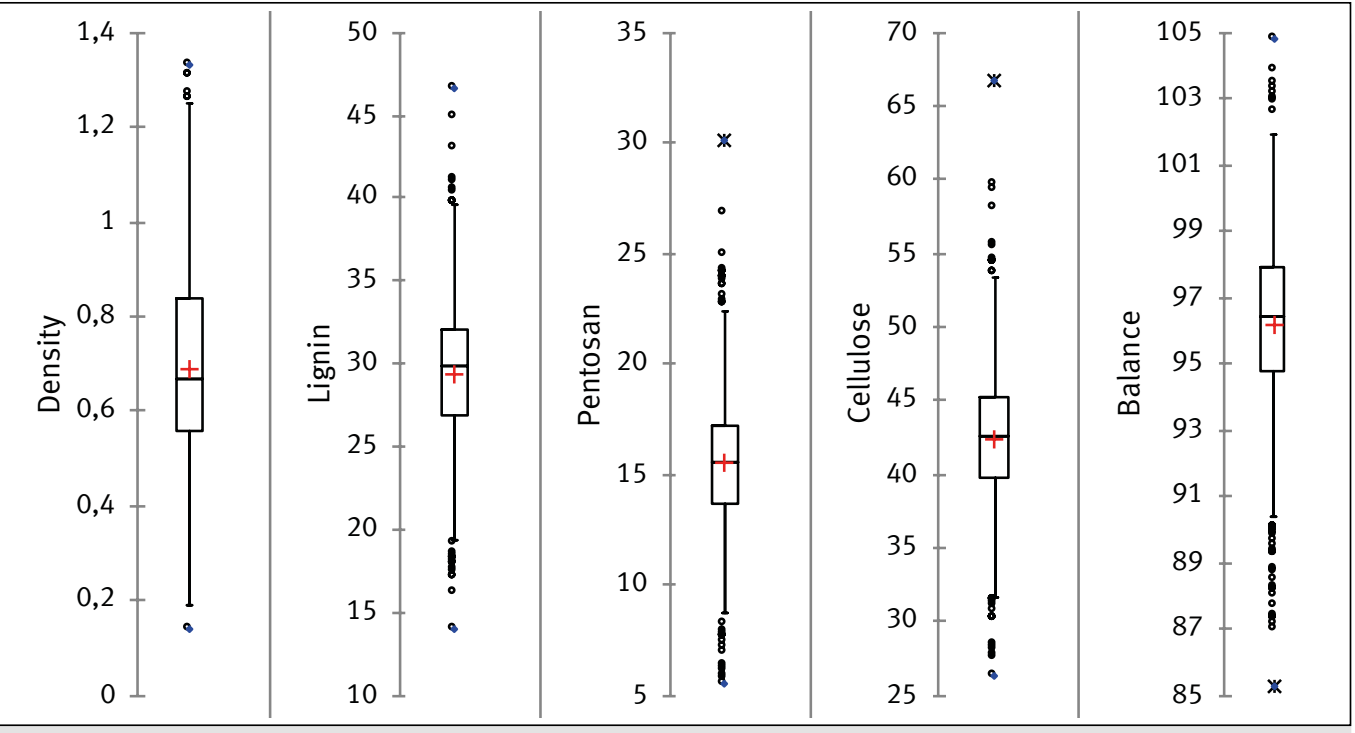

Figure 3.

Distribution of density and main components for all tests $(1,287)$. Values as a $\%$ related to anhydrous wood mass. Balance $=$ Extraneous content + Lignin + Pentosan + Cellulose. 
The coefficient of variation (CV) was always small (around 5\%) for the constitutive polymers (table I) and there were clear differences between trees, even within the same species (4 trees for Terminalia superba).

The CV was rather high (around 25\%) for extraneous components, but differences between mean tree values were also rather high, so there were clear differences between trees, even within the same species (figure 1).

For silica content, there was a contrast between so called "siliceous species" of the Dacryodes genus, with values always above 1,500 ppm, and the other species, with values always below $200 \mathrm{ppm}$ and always below $50 \mathrm{ppm}$ for half of the trees. For these "common" trees, the CV was very high (between $50 \%$ and $150 \%$ ) and it was pointless seeking distinctions between trees for this parameter. For the two siliceous trees $(17722,17878)$, the CV was much lower (around 15\%) and it seemed possible, in this small sample, to see clear differences between the two trees.
Overall, for most of the chemical parameters, it was possible to have distinctions between trees (even within the same species), either because of a small CV (main components), or due to large mean per tree differences with a rather high CV (extraneous components).

\section{Within-species level}

There were some cases of measurements on different trees within a species. Using those with at least 10 trees by species (12 species belonging to 11 genera), it was possible to take a look at the within-species variability of chemistry (figure 2, table II).

The coefficient of variation (CV) was rather small (around 10\%) for density, but the differences between mean values per species were large. Density was a rather good criterion for species separation.

Table II.

Variability within species represented by at least 10 trees. Top: mean values; bottom: coefficient of variation; Id: CTFT identifier; $\mathrm{Nb}$ : number of tests for the tree; CV: coefficient of variation of mean values per species; D: density of the reference specimen for the tree in the wood collection; $A B$ ext: ethanol/ benzene extract; W ext: water extract; Ash: ash content; Sil: silica content; Lig: lignin content; Pent: pentosan content; Cell: cellulose content.

\begin{tabular}{|c|c|c|c|c|c|c|c|c|c|}
\hline Species & $\mathrm{Nb}$ & D & $A B$ ext & W ext & Ash & Sil & Lig & Pent & Cell \\
\hline Aucoumea klaineana & 12 & 0.43 & 1.78 & 1.48 & 0.59 & 0.165 & 29.7 & 15.2 & 45.5 \\
\hline Canarium madagascariense & 10 & 0.60 & 1.08 & 4.48 & 1.07 & 0.160 & 24.7 & 17.3 & 45.0 \\
\hline Dacryodes buettneri & 13 & 0.59 & 1.85 & 1.60 & 0.83 & 0.200 & 30.2 & 15.7 & 45.6 \\
\hline Khaya senegalensis & 10 & 0.79 & 7.81 & 4.62 & 1.15 & 0.020 & 28.9 & 16.7 & 37.9 \\
\hline Lophira alata & 10 & 1.06 & 0.86 & 2.66 & 0.43 & 0.023 & 39.7 & 13.2 & 40.0 \\
\hline Milicia excelsa & 14 & 0.64 & 9.97 & 4.04 & 2.96 & 0.009 & 27.2 & 16.0 & 36.9 \\
\hline Pycnanthus angolensis & 21 & 0.45 & 2.08 & 3.60 & 1.32 & 0.016 & 24.6 & 18.0 & 45.2 \\
\hline Tarrietia densiflora & 12 & 0.77 & 9.28 & 1.76 & 0.24 & 0.028 & 32.5 & 12.8 & 39.5 \\
\hline Tarrietia utilis & 14 & 0.63 & 4.81 & 2.37 & 0.59 & 0.022 & 30.7 & 14.2 & 41.8 \\
\hline Tectona grandis & 24 & 0.67 & 8.38 & 2.40 & 1.23 & 0.419 & 29.5 & 14.1 & 40.8 \\
\hline Terminalia superba & 39 & 0.53 & 2.61 & 4.80 & 1.87 & 0.009 & 29.0 & 15.5 & 43.0 \\
\hline Triplochiton scleroxylon & 16 & 0.39 & 1.99 & 2.28 & 2.19 & 0.019 & 32.4 & 17.0 & 40.4 \\
\hline Mean & & 0.63 & 4.37 & 3.01 & 1.21 & 0.091 & 29.9 & 15.5 & 41.8 \\
\hline Species & $\mathrm{Nb}$ & CV D & CV AB ext & CV W ext & CV Ash & CV Sil & CV Lig & CV Pent & CV Cell \\
\hline Aucoumea klaineana & 12 & $17 \%$ & $73 \%$ & $44 \%$ & $22 \%$ & $51 \%$ & $4.3 \%$ & $4.4 \%$ & $3.1 \%$ \\
\hline Canarium madagascariense & 10 & $8 \%$ & $79 \%$ & $52 \%$ & $40 \%$ & $168 \%$ & $5.2 \%$ & $7.6 \%$ & $4.0 \%$ \\
\hline Dacryodes buettneri & 13 & $7 \%$ & $47 \%$ & $32 \%$ & $25 \%$ & $50 \%$ & $5.5 \%$ & $6.2 \%$ & $3.6 \%$ \\
\hline Khaya senegalensis & 10 & $8 \%$ & $37 \%$ & $18 \%$ & $32 \%$ & $60 \%$ & $8.3 \%$ & $7.6 \%$ & $8.2 \%$ \\
\hline Lophira alata & 10 & $2 \%$ & $59 \%$ & $44 \%$ & $94 \%$ & $98 \%$ & $3.6 \%$ & $19.2 \%$ & $5.4 \%$ \\
\hline Milicia excelsa & 14 & $9 \%$ & $23 \%$ & $21 \%$ & $34 \%$ & $68 \%$ & $8.3 \%$ & $5.2 \%$ & $9.5 \%$ \\
\hline Pycnanthus angolensis & 21 & $14 \%$ & $54 \%$ & $29 \%$ & $28 \%$ & $101 \%$ & $6.6 \%$ & $6.3 \%$ & $5.4 \%$ \\
\hline Tarrietia densiflora & 12 & $8 \%$ & $42 \%$ & $24 \%$ & $41 \%$ & $130 \%$ & $4.7 \%$ & $6.4 \%$ & $11.4 \%$ \\
\hline Tarrietia utilis & 14 & $5 \%$ & $71 \%$ & $30 \%$ & $12 \%$ & $54 \%$ & $8.3 \%$ & $9.3 \%$ & $10.7 \%$ \\
\hline Tectona grandis & 24 & $11 \%$ & $44 \%$ & $23 \%$ & $34 \%$ & $93 \%$ & $6.2 \%$ & $12.0 \%$ & $6.0 \%$ \\
\hline Terminalia superba & 39 & $13 \%$ & $34 \%$ & $32 \%$ & $40 \%$ & $107 \%$ & $7.6 \%$ & $11.0 \%$ & $5.1 \%$ \\
\hline Triplochiton scleroxylon & 16 & $15 \%$ & $26 \%$ & $27 \%$ & $21 \%$ & $82 \%$ & $3.4 \%$ & $3.7 \%$ & $5.1 \%$ \\
\hline Mean & & $10 \%$ & $49 \%$ & $31 \%$ & $35 \%$ & $88 \%$ & $6.0 \%$ & $8.2 \%$ & $6.5 \%$ \\
\hline
\end{tabular}


The CV was high (around 40\%) for extraneous components and differences between mean species values were high. There were clearly species with low values (lower than $4 \%$ for extractives and lower than $1.5 \%$ for ashes) for one or other extraneous component. They never seemed to have high values (figure 2). Other species often had very high values for $A B$ extract (above $10 \%$ ), but the range of values was large and individual trees may have had a low value for this parameter. Although the differences seemed evident with 10 trees per species, using only one tree could lead to a wrong conclusion: a low value was not proof that a mean value would be low, but a high value seemed to be a good indicator of a high mean value. This was also true for water extract and ashes.

For silica content, there was a clear separation between siliceous species (many values over $1,000 \mathrm{ppm}$ ) and the common ones (no values over 100 ppm). However, inside the siliceous species, there were large differences between trees and it would be hazardous to make a classification within siliceous species based on only one tree.

For the constitutive polymers, the CV values were still rather weak and differences in mean values per species rather low (table II). In any event, there was a clear distinction between species for lignin content (figure 2).

Overall, for most of the chemical parameters, it was possible to find distinctions between species using 10 trees per species, but using only one tree could make some sense for density, or main component contents (allowing the separation of high, average, or low values species).

For extraneous components, there could be mistakes for low values when using only one tree, because of the very large variation in values between different trees of species with a high mean content.

In the case of silica, the best way was to look first at the anatomy data for the occurrence of specific criteria (Wheeler et al., 1989). If no silica was indicated, the silica content would stay at very low values (usually below $100 \mathrm{ppm}$ ). For siliceous species, silica content would be 10 to 100 times greater and deserved to be measured.

\section{Between-species level}

Most of the 614 species (67\%) were represented by only one tree and $7 \%$ had at least five trees. There were only 15 gymnosperm species and very few temperate hardwood species (5).

For the hardwoods, a wide range of densities was covered (table III) and the CV (27\%) was very similar to the CV of the wood collection (28\%). When compared to this density $\mathrm{CV}$, the CVs for lignin and cellulose content were much lower (14\% and $10 \%$, respectively). Extraneous components, such as ethanol/benzene extractives, hot water extractives or ash, had a much higher CV ( $81 \%, 60 \%$ or $76 \%)$. For silica, only $60 \%$ of the species were measured and there were huge differences (from less than $100 \mathrm{ppm}$ to more than $10,000 \mathrm{ppm})$.

For tropical woods, the total content of these extraneous components (figure 1) could reach 20 to $25 \%$. In this case, lignin and cellulose content based on gross wood mass were much smaller than usual and did not give an appropriate representation of cell wall material for most properties.

It was decided to add "relative values" for lignin (Lig rel), pentosan (Pen rel) and cellulose (Cel rel) contents (as a $\%$ ), which were the values resulting from measurement divided by [100 - AB ext - W ext - Ash] in order to have more comparative main polymer values.

Histograms of mean values at species level (figures 4, 5 and 6) showed two major tendencies: i) a more or less symmetrical distribution, not far from normal, but non-normal all the same, for density and the three main cell wall polymers: lignin, pentosan and cellulose and ii) highly dissymmetrical distributions, with long tails towards higher values, for extraneous components.

For each of these extraneous components, there seemed to be a minority of "extract-rich", "ashrich" or "silica-rich" woods composing the high value tails. For the majority of "common woods", estimated medians (a kind of mean value for common wood) could be: $2.1 \%$ for $A B$ extract, $2.4 \%$ for water extract, $0.7 \%$ for ashes and $70 \mathrm{ppm}$ for silica content.

The correlation between parameters was calculated for the mean values at species level (table IV). Relative values are used for the cell wall polymers. Due to the non-normal distribution of values, the Spearman test was used.

There were very significant negative correlations between the three cell wall polymer values. This was not surprising, as 
increasing the proportion of one of them could mechanically decreases the proportion of the others.

A positive correlation of wood density with lignin, but negative with cellulose, could be explained by the small difference in density between these components (the density of cellulose is lower than that of lignin). Positive correlations between density and extractives (mostly AB extract) could be explained by the additional weight provided by heartwood formation.

The highly significant correlation between extraneous components was difficult to interpret without more informa- tion on molecules or minerals and their putative role in the tree (wood protection). There may be some synergy between $A B$ and water extracts (such as hydrolysable tannins), choices between mineral (silica for example) and organic molecules, or simply the solubility of some minerals in hot water.

The highly significant correlation between both the extractive content, and polysaccharide polymers, which was negative with cellulose and positive with pentosan, was puzzling (no correlation with lignin).
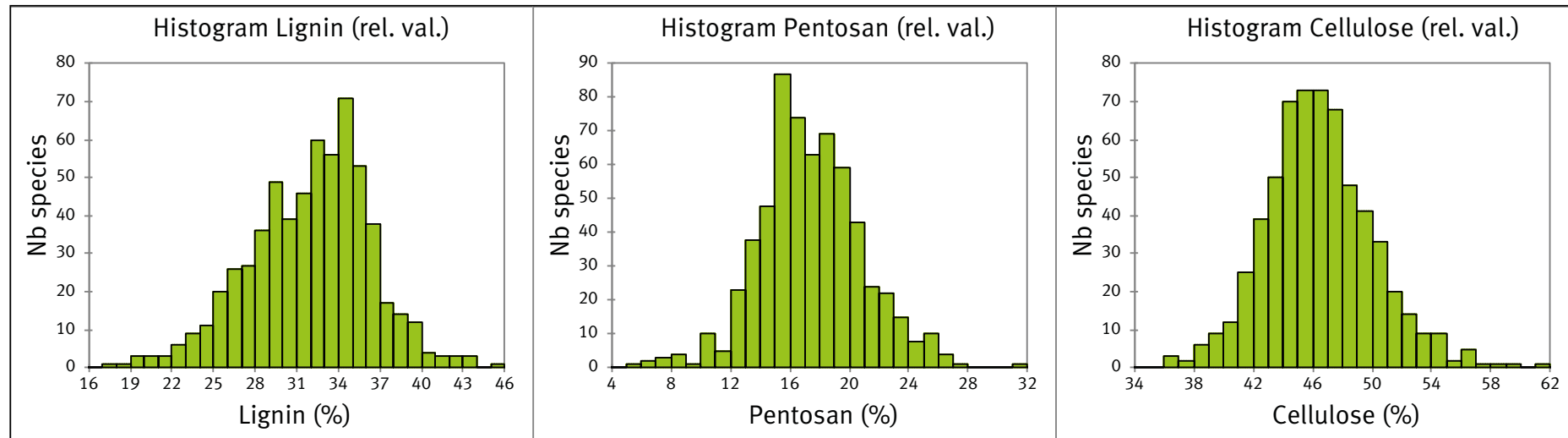

Figure 4.

Histogram of mean values per species for lignin, pentosan and cellulose content. rel. val.: relative values of the parameters.
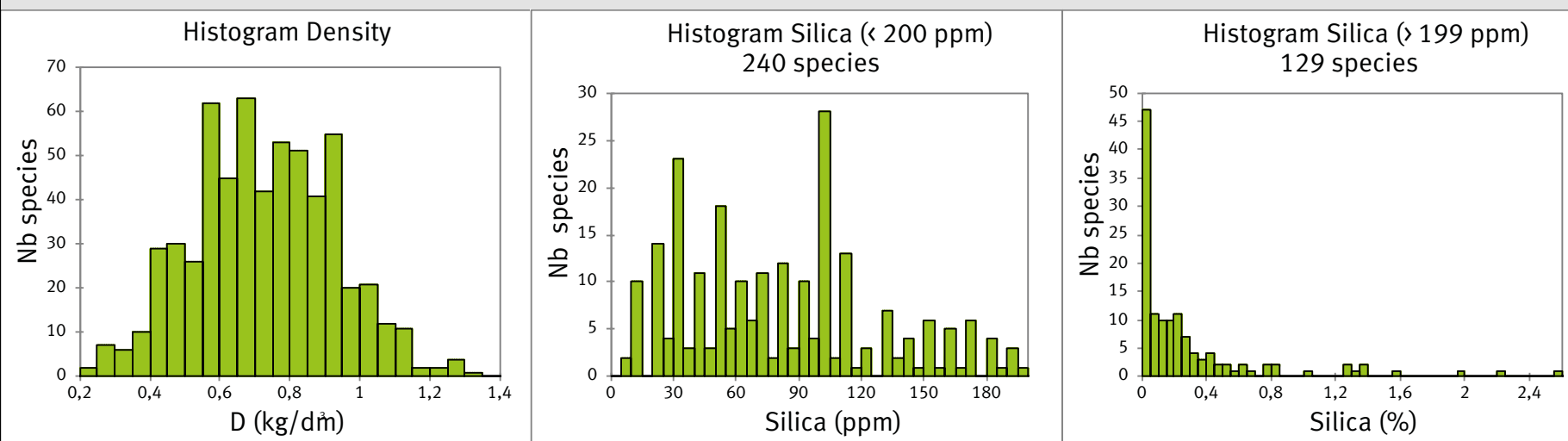

Figure 5.

Histogram of mean values per species for density and silica content. Silica values were split into two groups around an arbitrary value of $200 \mathrm{ppm}$, more or less separating siliceous species above $200 \mathrm{ppm}$.
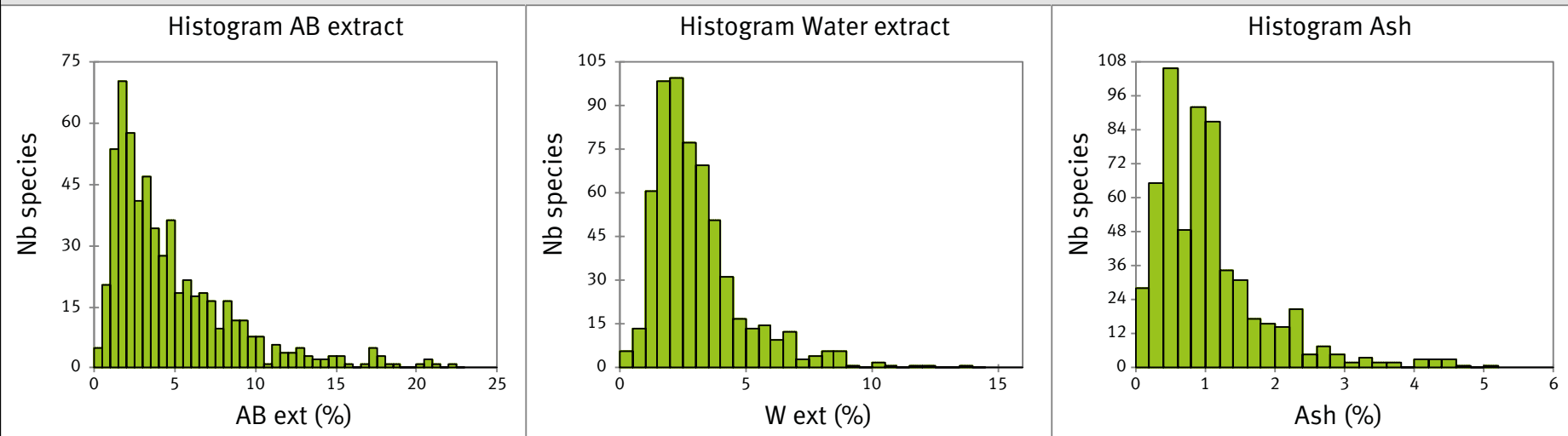

Figure 6.

Histogram of mean values per species for ash and extractives. $A B$ extract: ethanol/benzene extractives. Water extract: hot water extractives. The number of species is proportional to density (x300 for AB ext and W ext, and x120 for Ash). 


\section{Table IV.}

Spearman correlation table for mean per species values. Suppression of observation with incomplete data. Bold values are significant at the $0.1 \%$ level. D: density of the reference specimen for the tree in the wood collection; $A B$ ext: ethanol/benzene extract; W ext: water extract; Ash: ash content; Sil: silica content; Lig: lignin content; Pent: pentosan content; Cell: cellulose content.

\begin{tabular}{|l|c|c|c|c|c|c|c|}
\hline 593 species & D & AB ext & W ext & Ash & Lig & Pent & Cell \\
\hline D & 1 & 0.220 & 0.120 & -0.101 & 0.155 & 0.063 & -0.228 \\
\hline AB ext & 0.220 & 1 & 0.185 & -0.170 & 0.118 & 0.156 & -0.175 \\
\hline W ext & 0.120 & 0.185 & 1 & 0.223 & -0.040 & 0.291 & -0.143 \\
\hline Ash & -0.101 & -0.170 & 0.223 & 1 & -0.052 & 0.229 & -0.127 \\
\hline Lig & 0.155 & 0.118 & -0.040 & -0.052 & 1 & -0.487 & -0.441 \\
\hline Pent & 0.063 & 0.156 & 0.291 & 0.229 & -0.487 & 1 & -0.307 \\
\hline Cell & -0.228 & -0.175 & -0.143 & -0.127 & -0.441 & -0.307 & 1 \\
\hline
\end{tabular}

\section{Discussion}

The total of species measured represent around $10 \%$ of species present in the CIRAD wood collection. In some cases, the choice was guided by specific forests where there was a pulp and paper manufacture project (Le Cacheux, 1949; Pétroff, 1976; Tissot, 1989). In other cases it was guided by the necessity to have a large range of densities (Doat, 1977). Globally the necessity to cover a wide range of wood chemical composition was taken into account (Pétroff, 1960). The only way to predict a wide diversity of composition was to choose the widest diversity in density known from the wood collection (Langbour et al., 2018) and to use trees from different countries in the tropical region.

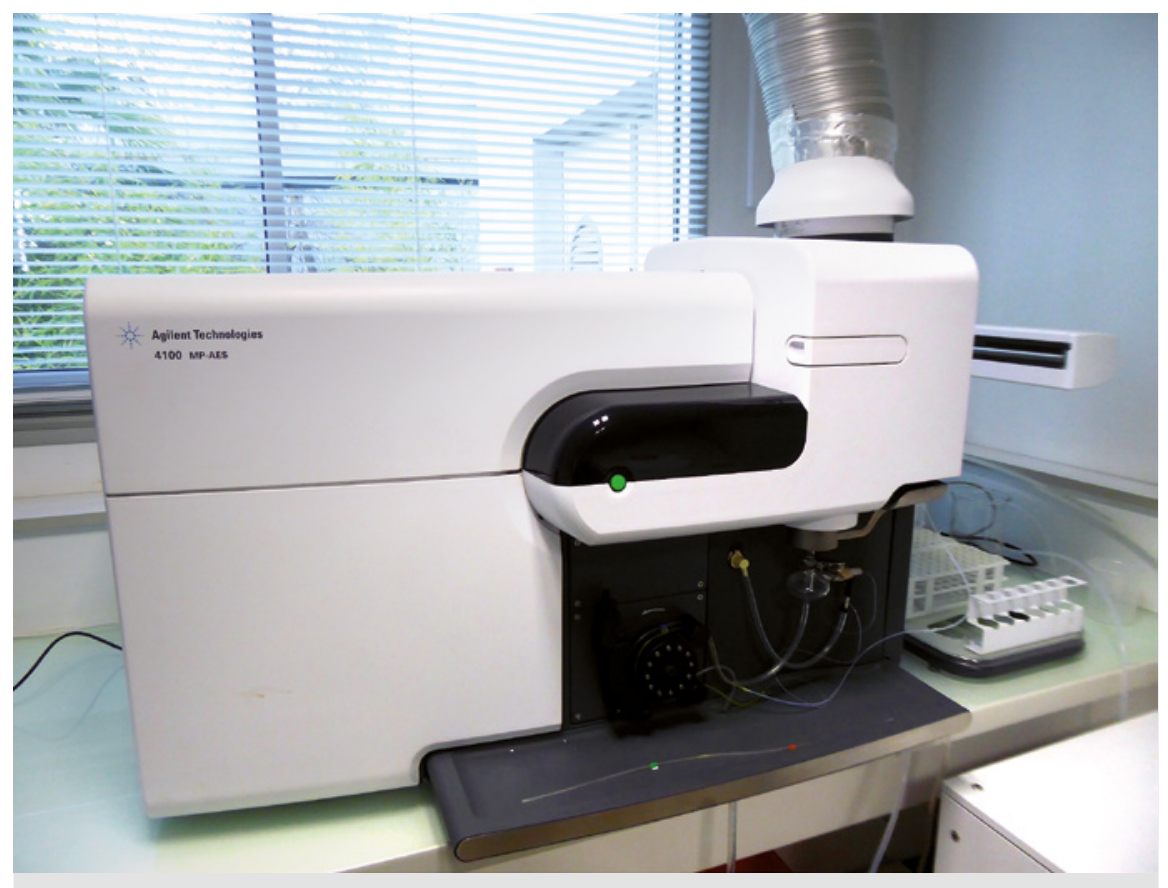

Photo 3.

Microwave Plasma Atomic Spectrometer (MP-AES, Chemistry Laboratory of the BioWooEB Unit - CIRAD).

Photo K. Candelier.
In the described data file we have only the country of provenance but nothing on provenance of the trees. By looking at trees with many tests or species with many trees we can only have a look on variability without being able to know its origin. It is quite obvious that genetics, environment and history are drivers of this intra tree, intra species variability. The answer, which is known in forest sciences, is that we need a minimum of samples by tree and a minimum of trees by species. Even being modest, this means between 10 and 100 times more measurements for these 600 species.

Anyway, the data file shows a very wide range of densities, of geographic provenances, of species, genera and families and looking at $10 \%$ of the whole set of species is an acceptable option. Given the rather high total number of tests in these conditions, it is highly likely that the whole range of chemical components contents was more or less covered. But from this data file, apart from a very small number of species, it is impossible to have a view of diversity within the species.

Studying the chemical composition of solid wood for all available species appeared as a challenge between 1930 and 1970 , driven by the pulp and paper industry. Pettersen (1984) published a reference paper with numerous chemical composition tables ( 9 tables of different provenances, both tropical and temperate), at species level, derived either from the literature or unpublished from his laboratory (FPL Madison, USA). In all, 600 species were referenced, including around 100 softwoods and 500 hardwoods ( $50 \%$ temperate, $50 \%$ tropical). The CTFT results were not included in the paper.

We did not find any available digital data, and it was interesting to enter into a computerized data file the values obtained at the FPL laboratory, always using the same protocol, very similar to that described by Savard et al. (1954), for 51 temperate hardwoods and 36 softwoods (there were no silica content measurements). For hardwoods, 60\% of the species were represented by only one tree ( $40 \%$ for softwoods). Only $2 \%$ of the hardwoods were represented by at least five trees (30\% for softwoods).

Table $\mathrm{V}$ and figure 3 give descriptive values for tropical hardwoods (594 species from this paper), temperate hardwoods (51 species from FPL in the Pettersen paper) and softwoods 
Table V.

Distribution of parameters for species: comparison between Pettersen and CTFT data (CTFT, French Technical Centre for Tropical Forests). All values (except for density) as a \% wood dry mass. From top to bottom: tropical hardwoods (CTFT); temperate hardwoods (Pettersen), softwoods (CTFT), softwoods (Pettersen. AB ext: ethanol/benzene extract; W ext: water extract; Ash: ash content; Sil: silica content; Lig: lignin content; Pent: pentosan content; Cell: cellulose content; Total: balance, summation of the $A B$ ext $+W$ ext + Ash + Lig + Pent + Cell parameters.

\begin{tabular}{|l|c|c|c|c|c|c|c|}
\hline 594 tropical species & AB ext & W ext & Ash & Lig & Pent & Cell & Total \\
\hline Minimum & 0.0 & 0.2 & 0.02 & 16.3 & 7.9 & 28.2 & 86.8 \\
\hline Maximum & 22.0 & 13.5 & 5.00 & 41.3 & 25.0 & 58.1 & 104.8 \\
\hline Median & 3.6 & 2.7 & 0.90 & 29.6 & 15.7 & 42.4 & 96.5 \\
\hline Mean & 4.8 & 3.1 & 1.08 & 29.2 & 15.9 & 42.3 & 96.3 \\
\hline CV & $81 \%$ & $60 \%$ & $76 \%$ & $14 \%$ & $17 \%$ & $10 \%$ & $2 \%$ \\
\hline 51 temperate species & AB ext & W ext & Ash & Lig & Pent & Cell & Total \\
\hline Minimum & 1.0 & 2.0 & 0.10 & 16.0 & 14.0 & 37.0 & 88.00 \\
\hline Maximum & 7.0 & 15.0 & 1.40 & 30.0 & 23.0 & 52.0 & 106.40 \\
\hline Median & 3.3 & 5.0 & 0.50 & 23.0 & 19.0 & 45.4 & 95.60 \\
\hline Mean & 3.6 & 5.0 & 0.54 & 23.1 & 19.4 & 45.3 & 96.31 \\
\hline CV & $38 \%$ & $51 \%$ & $53 \%$ & $13 \%$ & $11 \%$ & $7 \%$ & $4 \%$ \\
\hline 15 gymnosperm & & & & & & & \\
\hline species (CTFT) & AB ext & W ext & Ash & Lig & Pent & Cell & Total \\
\hline Minimum & 0.50 & 1.00 & 0.30 & 25.0 & 5.6 & 40.3 & 87.0 \\
\hline Maximum & 12.90 & 2.80 & 0.80 & 38.2 & 12.0 & 59.7 & 98.0 \\
\hline Median & 2.40 & 1.75 & 0.40 & 29.3 & 7.7 & 45.9 & 90.7 \\
\hline Mean & 3.45 & 1.83 & 0.44 & 29.9 & 8.3 & 47.5 & 91.3 \\
\hline CV & $94 \%$ & $29 \%$ & $41 \%$ & $11 \%$ & $22 \%$ & $10 \%$ & $4 \%$ \\
\hline 36 gymnosperm & & & & & & & \\
\hline species (Pettersen) & AB ext & W ext & Ash & Lig & Pent & Cell & Total \\
\hline Minimum & 0.10 & 1.00 & 0.10 & 25.0 & 5.0 & 37.0 & 83.30 \\
\hline Maximum & 2.00 & 14.00 & 0.50 & 35.0 & 14.0 & 49.0 & 95.90 \\
\hline Median & 2.72 & 3.97 & 0.32 & 28.8 & 9.8 & 43.7 & 89.27 \\
\hline Mean & $61 \%$ & $36 \%$ & $9 \%$ & $22 \%$ & $6 \%$ & $3 \%$ \\
\hline CV & & & & & & & \\
\hline
\end{tabular}

(15 species from this paper and 36 species from FPL in the Pettersen paper).

The main difference between hardwoods and softwood is the pentosan content. Most hardwood hemicelluloses are composed of 5 -carbon sugars, while softwood hemicelluloses have both 5-carbon and 6-carbon sugars (this is why the balance is much lower for softwoods). The mean lignin content was higher for softwoods (29\%) than for temperate hardwoods (23\%), but it was very similar to the mean value for tropical hardwoods. As for density, the range of values was much larger for tropical than for temperate hardwoods. It was rather common to separate softwoods, temperate and tropical hardwoods (Kollmann and Côté, 1968; Fengel and Wegener, 1984), but it seems very likely that the main difference between temperate and tropical hardwoods was the large difference in diversity. Temperate hardwoods looked like a sub-sample of total hardwoods with a lower range of composition and densities.

The level of chemical description that was chosen by wood laboratories at that period was rather coarse. A more detailed description (Stevanovic and Perrin, 2009) went more or less deeply into i) the proportion of the main three monomers of lignin (Olsson and Salmen, 1997), ii) the proportion of the complex mixture of hemicelluloses (Fagerstedt et al., 2014) derived from different basic sugars (6-carbon sugars, such as mannose or galactose, or 5-carbon sugars, such as xylose or arabinose), iii) the chemical signature of the specific cocktail of extractives (around one hundred per species) consisting of very different organic bio-active molecules, iv) the quantitative distribution of minerals within ash, where calcium, silica or aluminium can be very substantial, sometimes around $1 \%$ for hyper accumulators rather than several hundred $\mathrm{ppm}$ for most species Jansen et al., 2002; Gourlay and Grime, 1994; Kukachka and Miller, 1980). This is possible today thanks to new powerful tools (HPLC, GC/MS, LC) MS, etc.), but it is still rather lengthy, expensive and laborious if applied to thousands of species.

Using such detailed analysis is necessary for a description of wood diversity by chemotaxonomy (Pettersen, 1984; Royer et al., 2010), mostly based on extractives and mineral analyses. It is also useful to study the links between solid wood chemical composition and properties such as shrinkage, vibratory damping (Brémaud et al., 2011, 2013), resistance to insects and decay microorganisms (Neya et al., 2004; Amusant et al., 2014).

The question is: "Do we need to know the chemical composition of solid wood and at what level: wood in general, mean wood for a given forest biome, peculiar chemistry composition for a species or a group of species?" The answer is surely different for industrial purposes and for scientific investigations about relationships between chemical composition and wood properties. The fact remains that detailed or summary information on chemical composition is available today for less than $10 \%$ of tree species and this is clearly a serious handicap in making better use of forest biodiversity. 


\section{Conclusion}

The CTFT chemical composition database for tropical woods provides a relevant view of wood variability at the level of both main and extraneous components in tropical hardwoods, given the wide range of density of species ( 240 to $1,310 \mathrm{~kg} / \mathrm{m}^{3}$ ), the large number of species (614), genera (358), and families (89) representing respectively 7\%, 17\% and $39 \%$ of species, genera or families present in the CIRAD wood collection.

Values for main components (lignin, pentosan and cellulose) or extraneous components ( $A B$ and hot water extracts, ashes) are similar to literature data showing that temperate hardwoods values are included in the larger tropical hardwood range, in the same way as densities. Softwood species clearly differ from hardwoods for pentosan sugars that are less dominant among hemicelluloses in the softwoods.

Variability measured by the coefficient of variation (CV in \%) is lower for main components like cellulose (10\%), lignin $(14 \%)$ or pentosan (18\%) than for density $(27 \%)$, but much higher for extraneous components like water extracts $(60 \%)$, ethanol/benzene extract $(81 \%)$ or ash content (76\%). This means, on a statistical basis, that density should be investigated first before looking at main components influence, but the level of extraneous components should be investigated before density in each case when they are supposed to be active.

Dependency between variations of the parameters, measured by the square of the coefficient of correlation ( $R^{2}$ in \%), is not strong between density and chemical component content (less than 5\%) and within extraneous components (less than $5 \%$ ). It is not so strong between main and extraneous components (less than $8 \%$ ) and higher within main components (less than 25\%). At the same time the range of values (minimum - maximum) between tropical hardwood species is rather large for lignin content (17 to $41 \%$ ), pentosan content (6 to $31 \%$ ) or cellulose content (36 to $61 \%$ ), using relative values. It is huge for all extraneous components. There is a possibility to make, within the species of this data base, a selection of species with a high or a low value for density or one of the 6 chemical parameters (128 species) together with a small group of "standard" species with values around the median for all characters, in order to investigate the influence of basic chemistry on wood basic properties (shrinkage, mechanical behavior, resistance to fungi...).

Due to the very large variability of extraneous components content, it is impossible to categorize a species with only one tree. There are 235 species with at least 10 trees, each one having at least two duplicate samples in the CIRAD wood collection. It should be possible, using one of these duplicates to have a good chemical description of more than 200 tropical species.

An interesting prospective for further investigation should be to use the duplicate specimens of the CIRAD wood collection $(3,460$ species representing 10,800 trees have at least two duplicates specimens) for complementary chemical measurements: more species and more detailed investigation within monomers of lignin, hemicelluloses, molecules extracted by solvents or main mineral aggregates.

Apart from giving tools to investigate the role of chemical composition on wood properties, a systematic chemical study of wood extractives is a way to discover a great quantity of active molecules for different sectors as pharmacology, food industry, material improvement or cosmetics.

\section{References}

Amusant N., Migg M., Thibaut B., Brauchêne J., 2014. Diversity of decay resistance strategies of durable tropical woods species: Bocoa prouacencsis Aublet, Vouacapoua americana Aublet, Inga alba (Sw.) Wild. International Biodeterioration and Biodegradation, 94: 103-108. https:// doi.org/10.1016/j.ibiod.2014.06.012

Besson A., 1946. Richesse en cendres et teneur en silice des bois tropicaux. L'Agronomie Tropicale, 1 (1-2) : 44-50.

Brémaud I., Amusant N., Minato K., Gril J., Thibaut B., 2011. Effect of extractives on vibrational properties of African Padauk (Pterocarpus soyauxii Taub.). Wood Science and Technology, 45: 461-472. https://doi.org/10.1007/ s00226-010-0337-3

Brémaud I., Ruelle J., Thibaut A., Thibaut B., 2013. Changes in viscoelastic vibrational properties between compression and normal wood: roles of microfibril angle and of lignin. Holzforschung, 67: 75-85. https://doi.org/10.1515/ hf-2011-0186

Doat J., 1977. Le pouvoir calorifique des bois tropicaux. Bois et Forêts des Tropiques, 172 : 33-55. http://revues.cirad.fr/ index.php/BFT/article/view/19325

Ek M., Gellerstedt G., Henriksson G., 2009. Pulp and Paper Chemistry and Technology. Volume 1: Wood Chemistry and Wood Biotechnology. Berlin, Germany, De Gruyter, 208 p. https://doi.org/10.1515/9783110213409.147

Fagerstedt K. V., Mellerowicz E., Gorshkova T., Ruel K., Joseleau J.-P., 2014. Cell wall polymers in reaction wood. In: Gardiner B., Barnett J., Saranpää P., Gril J. (eds). The biology of reaction wood. Berlin, Germany, Springer-Verlag, 37-106. https://doi.org/10.1007/978-3-642-10814-3 3

Fengel D., Wegener G., 1984. Wood: Chemistry, Ultrastructure and Reactions. Berlin, Germany, De Gruyter, 613 p.

Gérard J., Narboni P., 1996. Une base de données sur les bois tropicaux. Bois et Forêts des Tropiques, 248 : 65-69. http://revues.cirad.fr/index.php/BFT/article/view/19885

Gérard J., Paradis S., Thibaut B., 2019. CIRAD wood chemical composition database. CIRAD Dataverse, France, V1. http:// dx.doi.org/10.18167/DVN1/U1FIU

Gourlay I. D., Grime G. W., 1994. Calcium-oxalate crystals in African Acacia species and their analysis by scanning proton microprobe (SPM). IAWA Journal, 15: 137-148. https://doi. org/10.1163/22941932-90001353

Hawley L. F., Wise L. E., 1926. The chemistry of wood. New York, USA, The Chemical Catalog Company, American Chemical Society Monograph Series, 334 p. 
Jansen S., Broadley M., Robbrecht E., Smets E., 2002. Aluminum hyperaccumulation in angiosperms: A review of its phylogenetic significance. Botanical Review, 68: 235-269. https://doi.org/10.1663/0006-8101(2002)068[0235:ahia ar]2.0.co;2

Kollmann F. P., Côté W. A. Jr., 1968. Principles of Wood Science and Technology. 1. Solid Wood. New York, USA, Springer-Verlag, $592 \mathrm{p}$.

Kukachka B. F., Miller R. B., 1980. A chemical spot-test for aluminum and its value in wood identification. IAWA Journal, 1: 104-109. https://doi.org/10.1163/2294193290000699

Langbour P., Paradis S., Thibaut B., 2018. CIRAD wood collection - Dataset. CIRAD Dataverse, France, V3. http:// dx.doi.org/10.18167/DVN1/CDHU51

Langbour P., Paradis S., Thibaut B., 2019. Description of the Cirad wood collection in Montpellier, France, representing eight thousand identified species. Bois et Forêts des Tropiques, 339: 7-16. https://doi.org/10.19182/ bft2019.339.a31709

Le Cacheux P., 1949. La cellulose tropicale. Bois et Forêts des Tropiques, 11 : 310-314. http://revues.cirad.fr/index. php/BFT/article/view/18378

Morize S., 1953. Analyse chimique des bois tropicaux. Thèse d’État ès sciences de l'Université de Paris, France, 191 p.

Neya B., Hakkou M., Pétrissans M., Gérardin P., 2004. On the durability of Burkea Africana heartwood: evidence of biocidal and hydrophobic properties responsible for durability. Annals of Forest Science, 61: 277-282. https:// doi.org/10.1051/forest:2004020

Olsson A. M., Salmen L., 1997. The effect of lignin composition on the viscoelastic properties of wood. Nordic Pulp and Paper Research Journal, 3: 140-144. https://doi. org/10.3183/npprj-1997-12-03-p140-144

Pétroff G., 1960. Considérations sur la production de pâte à papier à partir de bois tropicaux. Bois et Forêts des Tropiques, 71: 41-54. http://revues.cirad.fr/index.php/ BFT/article/view/18789

Pétroff G., 1965. Étude papetière de quelques échantillons d'eucalyptus congolais. Bois et Forêts des Tropiques, 103 : 27-38.

Pétroff G., 1976. Production expérimentale de pâte et papiers à partir de bois gabonais. Bois et Forêts des Tropiques, 166 : 39-45. http://revues.cirad.fr/index.php/ $\mathrm{BFT} /$ article/view/19293

Pétroff G., Doat J., 1978. Pyrolyse des bois tropicaux. Influence de la composition chimique des bois sur les produits de distillation. Bois et Forêts des Tropiques, 177 : 51-64. http://revues.cirad.fr/index.php/BFT/article/ view/19365

Pettersen R. C., 1984. The chemical composition of wood. In: Rowell R. M. (ed.). The chemistry of solid wood. Washington, DC, USA, American Chemical Society, Advances in Chemistry Series 20, 57-126. https://doi.org/10.1021/ba-19840207.ch002
Quint P. L., 1951. Reconnaissance des forêts tropicales en vue de la production de cellulose. Bois et Forêts des Tropiques, 19 : 100-108. http://revues.cirad.fr/index.php/ BFT/article/view/18433

Royer M., Herbette G., Eparvier V., Beauchêne J., Thibaut B., Stien D., 2010. Secondary metabolites of Bagassa guianensis Aubl. wood: a study of the chemotaxonomy of the Moraceae family. Phytochemistry, 71: 1708-1713. https://doi.org/10.1016/i.phytochem.2010.06.020

Savard J., Besson A., Morize S., 1954. Analyse chimique des bois tropicaux. Nogent-sur-Marne, France, Centre technique forestier tropical, $191 \mathrm{p}$.

Savard J., Nicolle J., André A. M., 1959. Analyse chimique des bois tropicaux. Tome II. Nogent-sur-Marne, France, Centre technique forestier tropical, $253 \mathrm{p}$.

Stevanovic T., Perrin D., 2009. Chimie du bois. Lausanne, Suisse, Presses polytechniques et universitaires romandes, $241 \mathrm{p}$.

Tissot M., 1989. Valorisation papetière de la forêt guyanaise. Bois et Forêts des Tropiques, 220 : 77-83. http://revues. cirad.fr/index.php/BFT/article/view/19633

Wheeler E. A., Baas P., Gasson P. E., 1989. IAWA list of microscopic features for hardwoods identification. IAWA Bulletin, 10 (3): 219-332. https://www.iawa-website. org/uploads/soft/Abstracts/IAWA \%20list $\% 20$ of\% 20 microscopic $\% 20$ features $\% 20$ for $\% 20$ hardwood $\% 20$ identification.pdf

\begin{tabular}{|c|c|}
\hline \multicolumn{2}{|c|}{ Gérard et al. - Author's contributions } \\
\hline CONTRIBUTOR ROLE & CONTRIBUTOR NAMES \\
\hline Conceptualization & B. Thibaut, J. Gérard \\
\hline Data Curation & J. Gérard \\
\hline Formal Analysis & B. Thibaut \\
\hline Software & S. Paradis \\
\hline Visualization & B. Thibaut, S. Paradis \\
\hline $\begin{array}{l}\text { Writing - Original Draft } \\
\text { Preparation }\end{array}$ & B. Thibaut, J. Gérard \\
\hline $\begin{array}{l}\text { Writing - Review } \\
\text { \& Editing }\end{array}$ & $\begin{array}{l}\text { J. Gérard, B. Thibaut, } \\
\text { S. Paradis }\end{array}$ \\
\hline
\end{tabular}

Bois et Forêts des Tropiques - Revue scientifique du Cirad
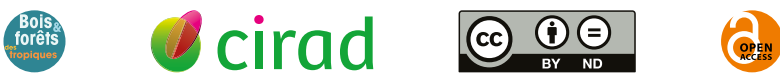

Cirad - Campus international de Baillarguet, 34398 Montpellier Cedex 5, France - Contact : bft@cirad.fr - ISSN : L-0006-579X 